\title{
Natural Seedling Recruitment and Regeneration in Deforested and Sand-Filled Mangrove Forest at Eagle Island, Niger Delta Nigeria
}

\author{
Aroloye O. Numbere ${ }^{1}$ \\ ${ }^{1}$ University of Port Harcourt
}

December 3, 2020

\begin{abstract}
Seed recruitment is a major driver of mangrove restoration globally. It is hypothesized that soil condition and channel hydrology can accelerate seedling recruitment and regeneration after a major disturbance. Species abundance, diversity indices, microbial and chemical concentrations in sand-filled mangrove forest was studied. Eight plots (area $=3902.16 \mathrm{~m} 2)$ were established with ten transects in each plot in a random block design to investigate the effect of soil conditions on seedling growth. A total of 1 , 886 seedlings were physically counted. Seedling abundance was significantly different between red (Rizophora racemosa), white (Laguncularia racemosa) and black (Avicennia germinans) mangroves and nypa palm (nypa fruticans). The most dominant species was black mangroves and the least dominant species was nypa palm. Muddy soils had the most abundant species while sandy soils had the least abundant species. Furthermore, semi-muddy soils had the highest species diversity $(\mathrm{H}=0.948)$ whereas muddy soils had the least species diversity $(\mathrm{H}=0.022)$. The soil metal concentration has no correlation with seed abundance and occur in the order Iron $>$ Nitrate $>$ Copper $>$ Cadmium. Soil with high species diversity had high soil microbial population; however, seedling abundance was correlated with soil nutrients and not heavy metals. Small seeds are easily recruited while good soil condition plus existing hydrological connection facilitated natural seedling regeneration in the disturbed mangrove forest.
\end{abstract}

\section{Hosted file}

Mangrove seedling recruitment_Ecol_Evo_CORRECTIONS_FINAL.docx available at https://authorea. com/users/380990/articles/496791-natural-seedling-recruitment-and-regeneration-indeforested-and-sand-filled-mangrove-forest-at-eagle-island-niger-delta-nigeria 